\title{
New and poorly known Oriental species of leaf beetles (Coleoptera: Chrysomelidae)
}

\section{Новые и малоизвестные ориентальные виды Аистоедов (Coleoptera: Chrysomelidae)}

\author{
L.N. Medvedev \\ A.H. Медведев
}

Institute for Problems of Ecology and Evolution, Russian Academy of Sciences, Leninsky prospect 33, Moscow 119071 Russia
Институт проблем экологии и эволюции РАН, Ленинский проспект 33, Москва 119071, Россия

KEY WORDS: Chrysomelidae, Oriental region, new taxa, new synonym.

КЛЮЧЕВЫЕ СЛОВА: Chrysomelidae, Ориентальная область, новые таксоны, новый синоним.

ABSTRACT. 7 new species and 1 subspecies of Chrysomelidae are described: Lema gorbunovi (Thailand), L. feae malayana (Malacca), Aetheomorpha nigroapicata, Ae. prokofievi (Vietnam), Mireditha curtipennis (China), Hemipyxis manfredi (Vietnam), Lanka nigricollis, Paraphthona opaca (Thailand). Lema rugifrons Jacoby, 1889 is a new synonym of L. fulvula Lacordaire, 1845.

РЕЗЮМЕ. Описывается 7 новых видов и 1 подвид Chrysomelidae: Lema gorbunovi (Таиланд), L. feae malayana (Малакка), Aetheomorpha nigroapicata, Ae. prokofievi (Въетнам), Mireditha curtipennis (Китай), Hemipyxis manfredi (Вьетнам), Lanka nigricollis, Paraphthona ораса (Таиланд). Lema rugifrons Jacoby, 1889, сводится в синонимы к L. fulvula Lacordaire, 1845.

Chrysomelidae of South East Asia are studied very intensively in the last time. Nevertheless, new collected materials very often include new species and sometimes even genera. Below I describe a few new species received from different collectors and partly from Basel Museum of Natural History.

Depositary places: NHMB - Naturhistorisches Museum in Basel; cLM - the author's collection.

Lema (s.str.) gorbunovi Medvedev sp.n.

MATERIAL. Holotype (sex not determined): N. Thailand,

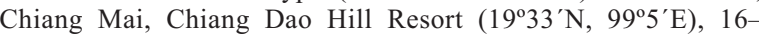
22. VIII.2010, $540 \mathrm{~m}$, leg. O. Gorbunov (cLM).

DESCRIPTION. Fulvous, antennae black with two basal and two apical segments fulvous.

Head as wide as prothorax at anterior margin, shining, very finely and sparsely punctuate, obliquely grooved on each side of interocular area, frontoclypeus finely pubescent, vertex convex, without central impression, gena $3 / 4$ as deep as eye. Antennae reach middle of elytra, proportions of segments are as 11-6-8-6-10-9-8-7-7-7-7, preapical segments about $2-2.3$ times as long as wide. Prothorax as long as wide at fore and hind margins, collared anteriorly, strongly constricted just behind middle, anterior angles obtuse, sur- face shiny, impunctate, with two transverse grooves: one in basal third, another before middle, interrupted in center. Scutellum small, subquadrate with truncate hind margin, impunctate. Elytra 1.6 times as long as wide, slightly narrowed to behind, with 10 regular rows of punctures at middle and postbasal impression, punctures in rows a little larger and more widely spaced anteriorly, finer and a little closely spaced posteriorly. Underside smooth, minutely punctuate. Tibiae straight, not modified. Hind tarsal segment 1 about as long as $2+3$. Length of body $5.7 \mathrm{~mm}$.

DIAGNOSIS. This species belongs to rather small group of fulvous species with two transverse impressions on prothorax. It is similar to L. decolorata Jacoby, 1908 and L. feae Jacoby, 1892 (see a key below).

ETIMOLOGY. The species named after its collector.

1(2) Vertex flat, densely covered with fine hairs. Labrum and anterior portion of frontoclypeus black. Antennae black with fulvous basal segments, but very often all black segments have fulvous base or fulvous beneath. Underside black to fulvous, breast mostly black on sides, abdomen mainly with black sternites margined on base and sides with fulvous. Legs fulvous with more or less darkened tibiae and dark tarsi. Length 4.0-5.4 mm. South India, Sri Lanka, Burma, Thailand, Laos, Vietnam, Taiwan, Peninsular Malaysia, Sumatra, Nias. Feeding on Oryza sativa..................... L. fulvula Lacordaire, 1845

2(1) Vertex distinctly convex, not pubescent.

3(12) Labrum black.

4(11) Antennae at least partly black.

5(6) Underside fulvous, legs piceous, head fulvous, antennae entirely black. Vertex sparsely punctate, with deep central groove. Prothorax with a few fine punctures at middle. Length $6.5 \mathrm{~mm}$. East India. Only a single type specimen is known. ...................... L. pallidetestacea Clark, 1866.

6(5) Underside at least partly black. Head fulvous with clypeus usually more or less black.

7(10) Continental species. Antennae entirely black.

8(9) Legs black with fore femora more or less fulvous beneath. Underside entirely black. Vertex with central groove. Length 5.6-5.8 mm. South China, Vietnam, Thailand. Indication for Borneo: Sabah (Mohamedsaid, 2004) possibly belongs to $L$. haematomelas Lacordaire. .......... L. perplexa Baly, 1882

9(8) Legs entirely black. Underside black with apical abdominal segments margined with fulvous. Vertex without 

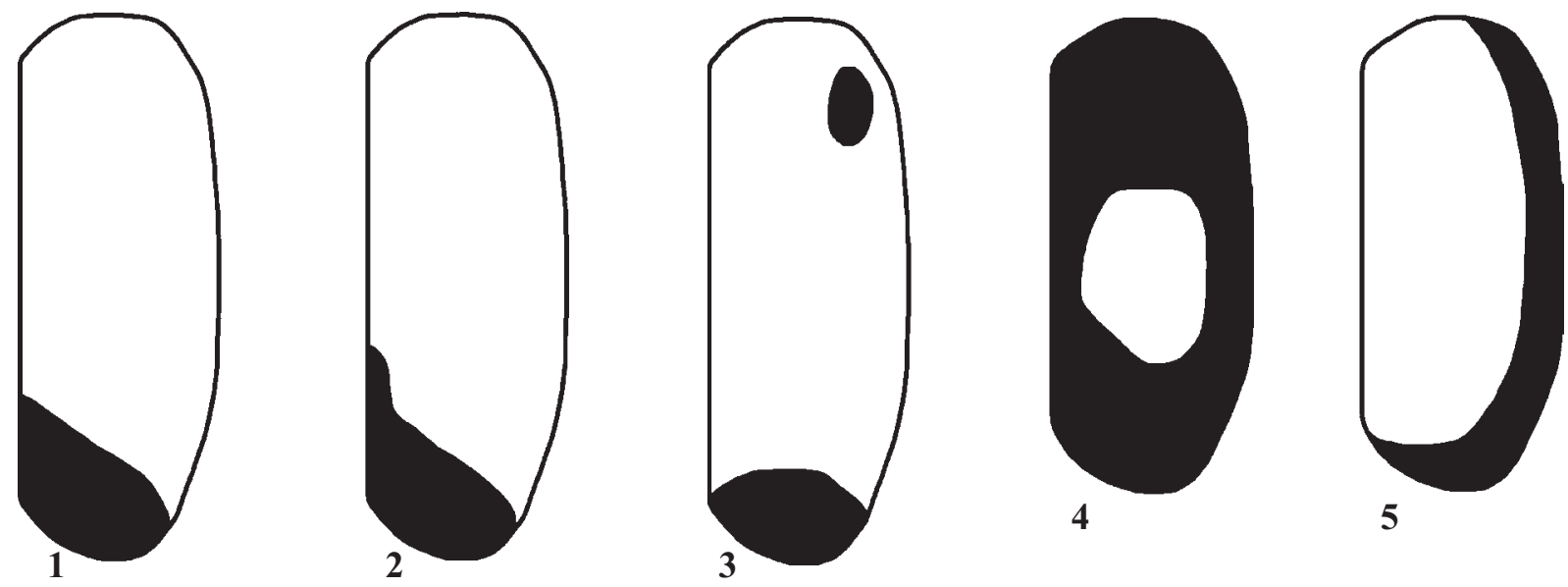

Figs 1-5. Elytral pattern: 1-2 - Aetheomorpha nigroapicata; 3 - Ae. prokofievi; 4 - Hemipyxis manfredi; 5-Lanka nigricollis. Рис. 1-5. Рисунок надкрылий: 1-2 — Aetheomorpha nigroapicata; 3 -Ae. prokofievi; 4 — Hemipyxis manfredi; 5 — Lanka nigricollis.

central groove. Length 7-8 mm. India: Assam.

L. assamensis Jacoby, 1891

10(7) Species from South-East islands. Antennae black with fulvous basal segments. Breast black, abdomen fulvous to black, legs black with fore and mid femora partly fulvous. Vertex with central groove. Length 5.5-6.3 mm. Java, Sumatra, Lombock. .... L. haematomelas Lacordaire, 1845

11(4) Antennae fulvous. Clypeus black to metallic blue, underside fulvous with black sides of breast, legs fulvous. Vertex with central groove. Length 5.0-6.0 mm. India.

\section{L. maheensis Jacoby, 1898}

12(3) Labrum fulvous.

13(14) Clypeus bluish black, closely pubescent. Antennae black, with widened apical segments. Underside fulvous with bluish black sides of breast, legs bluish black. Elytra with feeble iridescent gloss. Vertex with central groove. Length $6 \mathrm{~mm}$. Burma........... L. clypeata Jacoby, 1908

14(13) Clypeus fulvous, without dense pubescence. Elytra without iridescent gloss. Legs at least partly fulvous.

15(18) Antennae black with a few fulvous segments.

16(17) Vertex with short central groove. Antennae black with fulvous basal segments. Underside fulvous, legs fulvous with apices of tibiae and tarsi obscure fuscous. Length 4.5 $5.0 \mathrm{~mm}$. South India. .......... L. decolorata Jacoby, 1908

17(16) Vertex without central groove. Antennae black with two basal and two apical segments fulvous. Underside and legs fulvous. Length $5.7 \mathrm{~mm}$. Thailand. . L. gorbunovi sp. n.

18(15) Antennae fulvous, breast black. Vertex without central groove.

19(20) Legs fulvous. Anterior transverse furrow of prothorax not interrupted in middle. Abdomen fulvous with two basal segments black. Length 5.5-5.8 mm. Vietnam, Thailand, Burma, China (Yunnan)........ L. feae feae Jacoby, 1892

20(19) Legs fulvous with basal halfs of mid and hind femora black. Abdomen fulvous with black basal segment. Anterior transverse furrow of prothorax interrupted in middle. Length $5.7-5.9 \mathrm{~mm}$. Malacca. L. feae malaysiana sbsp. $\mathbf{n}$.

\section{Lema (s.str.) fulvula Lacordaire, 1845}

Lema rugifrons Jacoby, 1889 , syn. $\mathbf{n}$.

In the original description of L. rugifrons Jacoby indicated that it is unique species in Oriental fauna with flat and pubescent vertex [Jacoby, 1889]. It means that he overlooked Lacordaire's description. Later he included L. fulvula Lacordaire erroneously in the section V instead of section VI, in which he placed quite correctly a species described by him (Jacoby, 1908). I studied a type of L. rugifrons Jacoby and a specimen from Nias determined by Pinsdorf as L. fulvula Lacordaire and found that they are quite identical.

\section{Lema (s.str.) feae malaysiana subsp. $\mathbf{n}$.}

MATERIAL. Holotype (sex not determined): Malaysia, Benom Mts., 15 km E Kampong Dong ( $\left.3^{\circ} 53^{\prime} \mathrm{N}, 102^{\circ} 1^{\prime} \mathrm{E}\right), 700 \mathrm{~m}$, 1.IV.1998, leg.Dembicky \& Pacholatko (NHMB). Paratype: same label, 1 ex. (cLM).

DESCRIPTION. This form morphologically identical to the nominative form and differs only in two points: anterior transverse impression of prothorax interrupted in middle; basal halfes of mid and hind femora black.

DIAGNOSIS. See the key. Nominative subspecies is distributed in Burma and Indochina, a new subspecies was found on Malay Peninsula.

\section{Aetheomorpha nigroapicata Medvedev sp.n.} Figs 1-2, 6

MATERIAL. Holotype: $\bigcirc^{7}$, Vietnam, Khanh Hoa, $72 \mathrm{~km}$ to Dalat $\left(12^{\circ} 14^{\prime} \mathrm{N}, 108^{\circ} 46^{\prime \prime} \mathrm{E}\right), 750-800 \mathrm{~m}, 27-29 . \mathrm{IV} .2010$, leg. A. Prokofiev (cLM). Paratype: same locality and date, 1 + (cLM).

DESCRIPTION. Fulvous, elytra more pale behind middle, antennae except 3 or 4 basal segments and apices of elytra black, this black colour in female partly produced anteriorly along suture (Figs 1-2). Body parallel-sided in male, distinctly widened to behind in female. Head almost impunctate except a group of punctures along inner margin of eye and more strong in male, anterior margin of clypeus very feebly concave, frons of male 1.25 times as wide as transverse diameter of eye, with deep central groove, in female corresponding twice as wide as eye, with 3 feeble grooves. Antennae strongly serrate from the $4^{\text {th }}$ segment, $4^{\text {th }}$ segment triangular as wide as long, next segments (except apical) feebly transverse. Prothorax twice as wide as long, broadest in basal third, side margins rounded, hind angles broadly rounded and not elevated, surface shining and impunctate except basal margin before scutellum which is impressed and has a few punctures. Scutellum large, triangular, its apex slightly elevated above elytral level, surface shining and impunctate. Elytra 1.5 times $\left(\sigma^{7}\right)$ and 1.35 times $(+)$ as long as wide, surface shining, with distinct and moderately dense punctures, more feeble on apical slope, epipleural area of elytron broadly lobed. Pygidium entirely exposed in both sexes. Propleurae bare. Segment 1 of fore tarsi not widened in male. Aedeagus (Fig .6) with very thin and long apical process curved downward, underside of aedeagus with central ridge in apical half. 


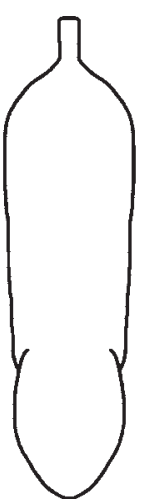

6
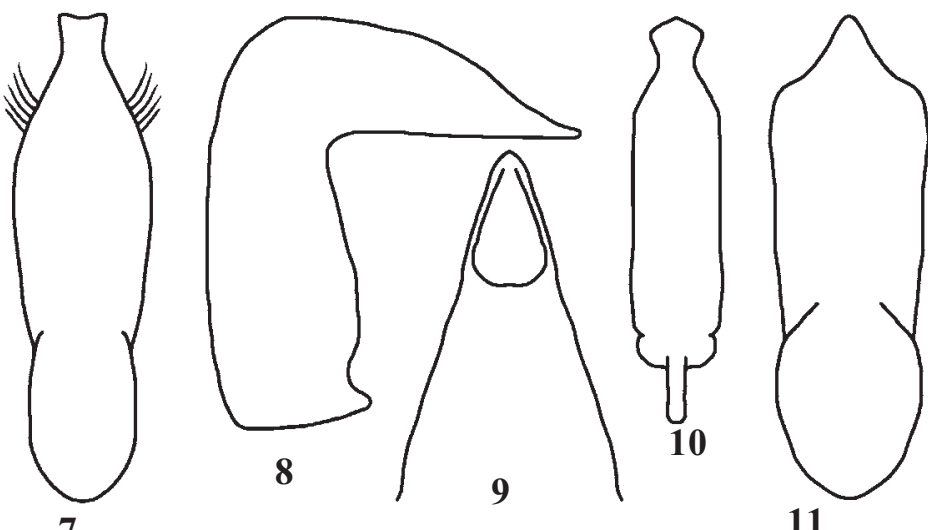

11

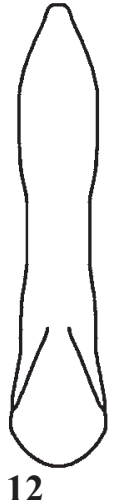

12

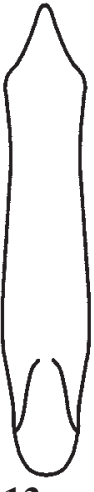

13

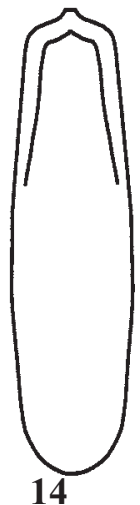

14

Figs 6-14. Aedeagus: 6 - Aetheomorpha nigroapicata; 7 - Ae. prokofievi; 8-9 - Mireditha curtipennis; 10 - Hemipyxis manfredi; 11 - Lanka nigricollis; 12 - Paraphthona opaca; 13 - P.geiseri; 14 - P.mostovskii; 6-7, 10-14 - ventral view; 8 - lateral view; 9 - dorsal view.

Рис. 6-14. Эдеагус: 6 - Aetheomorpha nigroapicata; 7 - Ae. prokofievi; 8-9-Mireditha curtipennis; 10 - Hemipyxis manfredi; 11 - Lanka nigricollis; 12 - Paraphthona opaca; 13 - P.geiseri; 14 - P.mostovskii; 6-7,10-14 - снизу; 8- сбоку; 9 - сверху.

Length of male $3.4 \mathrm{~mm}$, of female $4.3 \mathrm{~mm}$.

DIAGNOSIS. Only one species of this genus, Ae. apicata L. Medvedev, 1988 has elytra fulvous with black apices and distributed only in the Himalaya. A new species differs immediately with black antennae, fulvous pygidium and breast and especially in form of aedeagus.

ETIMOLOGY. The species named after the black-colored elytrae apices.

\section{Aetheomorpha prokofievi Medvedev sp.n.} Figs 3, 7

MATERIAL. Holotype: $\sigma^{7}$, Vietnam, Khanh Hoa, $72 \mathrm{~km}$ to Dalat $\left(12^{\circ} 14^{\prime} \mathrm{N}, 108^{\circ} 46^{\prime} \mathrm{E}\right), 750-800 \mathrm{~m}, 27-29 . I V .2010$, leg. A. Prokofiev (cLM). Paratypes: same locality and date, $1 \mathrm{O}^{7}$ (MS), $1 \mathrm{O}^{7}$ (cLM).

DESCRIPTION. Head black with fulvous clypeus and labrum, antennae black with 3 basal joints fulvous, prothorax fulvous, scutellum fulvous or partly darkened on sides (males) or black, elytra fulvous with black humeral spot and apex (fig .3), in male paratype with narrow black emargination of apex, underside black, legs fulvous with more or less black femora.

Body parallel-sided in male, distinctly widened posteriorly in female. Clypeus impunctate, with slightly concave anterior margin, frons finely punctuate, with 3 feeble grooves, vertex strongly convex, shining and impunctate, frons $1.4\left(O^{7}\right)$ or 1.75 (+) times as wide as transverse diameter of eye. Antennae strongly serrate from the $4^{\text {th }}$ segment, segment 4 triangular and as long as wide, next segments except apical irregularly subquadrate and feebly transverse. Prothorax twice as wide as long, broadest just before base, side margins feebly rounded, hind angles broadly rounded and not elevated, surface shining and impunctate except a few punctures on basal margin. Scutellum triangular with apex scarcely elevated, surface shining and impunctate. Elytra $1.4\left(\mathrm{O}^{7}\right)$ and $1.25(+)$ as long as wide, surface shining with rather dense punctures, diminished on apical slope, epipleural lobe of elytron broadly rounded, very distinct. Pygidium and in female preceding tergite entirely exposed. Propleurae bare. Segment 1 of anterior tarsi moderately widened in male. Aedeagus with finger-like process slightly excavated on apex and curved downward, underside strongly convex, longitudinally ridged in apical quarter (Fig. 7). Length of male $4.6-4.9 \mathrm{~mm}$, of female $5.5 \mathrm{~mm}$.

DIAGNOSIS. This species differs from preceding and from Ae. apicata L. Medvedev, 1988 with bicolor head, humeral spot on elytra, black underside and form of aedeagus.

ETIMOLOGY. The species is named after its collector.

\section{Mireditha curtipennis Medvedev sp.n.}

Figs 8-9, 15

MATERIAL. Holotype: $0^{7}$, China, Yunnan prov., Jinsha river $\left(27^{\circ}\right.$ $\left.18^{\prime} \mathrm{N}, 100^{\circ} 13^{\prime} \mathrm{E}\right)$, Daju, 1950-2050 m, 15-17.VII.1990, leg. V. Kuban (NHMB). Paratypes: same locality, 7 ex. (NHMB, 2 ex. - cLM).

DESCRIPTION. Metallic bronze, labrum, anterior portion of clypeus, 5 or 6 basal segments of antennae and legs fulvous, apical antennal segments piceous, underside piceous to black, but apical abdominal sternites sometimes lighter.

Body short ovate. Head strongly and densely punctuate, clypeus not divided from frons, with shallow emargination in middle of anterior margin, frons and vertex without any impressions.

Antennae reach humeral elytral area, proportions of segments are as 6-4-2-3-5-5-6-6-5-5-7, five apical segments thickened, about 1.3-1.5 times as long as wide. Prothorax 1.5 times as wide as long, broadest on level of lateral prebasal angulation, sides between anterior angles and prebasal angulation feebly arcuate, further deeply incised (Fig. 15), surface very convex, shining, finely and densely punctate. Scutellum small, triangular, shining and smooth. Elytra of male as long as wide, of female 1.1 times as long as wide, not produced laterally in humeral area, coalescent, with distinct humeral tubercle and oblique ridge along anterior part of side margin, surface shining, elytral rows distinct to apex, interspaces broad and flat, but two marginal ones moderately convex in female. Wings absent.

Anterior tarsi, especially the first segment, widened in male. Aedeagus (Fig. 8-9) narrowed from base to obtusely rounded apex. Length $2.6-3.1 \mathrm{~mm}$.

DIAGNOSIS. Near M. cribraria Tan, 1981 and M. intermedia Tan, 1992, differs from both in strongly angulate lateral

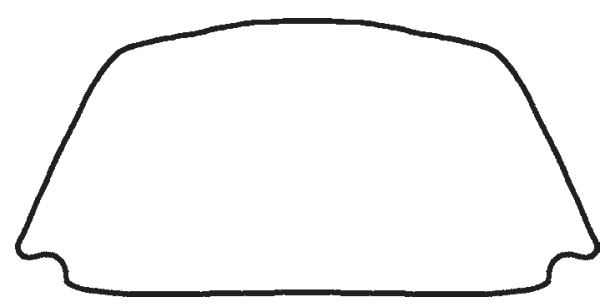

Fig. 15. Prothorax of Mireditha curtipennis

Рис. 15. Переднеспинка Mireditha curtipennis 
margin of prothorax and more short elytra. Besides, M. cribraria has very strongly punctuated prothorax, $M$. intermedia has black legs and broadly truncated apex of aedeagus.

ETIMOLOGY. The species named after the shape of elytrae.

\section{Hemipyxis manfredi Medvedev sp.n.} Figs 4, 10

MATERIAL. Holotype: $\sigma^{7}$, Vietnam, Tam Dao, $900 \mathrm{~m}$, 16.VII.1982, leg. L. Medvedev (cLM).

DESCRIPTION. Head, prothorax and scutellum red, antennae black with 3 basal segments red, elytra black with pale flavous spot in middle (Fig .4), underside and legs fulvous.

Body ovate. Head impunctate, interantennal space very narrow, with feeble ridge, frontal tubercles rhomboidal with more acute anterior angle. Antennae reach behind middle of elytra, nitidiform, without thickened intermediate segments, proportions of segments are as 7-3-6-6-6-6-6-6-5-5-7, preapical segments about 3.0-3.5 times as long as wide. Prothorax twice as wide as long, broadest in middle, anterior angles broadly rounded, side margins feebly arcuate and moderately expanded, surface convex, shining, with sparse microscopic punctures. Scutellum triangular, impunctate. Elytra ovate, 1.2 times as long as wide, with sides narrowly expanded, surface moderately convex, shining, distinctly punctuate, but much more feeble on apical slope. Last abdominal sternite impressed in middle, with dark central line. Aedeagus (Fig. 10) thick in lateral view and with specific protuberance on apex. Length of body $3.9 \mathrm{~mm}$.

DIAGNOSIS.This species has general appearance of $H$. kimotoi Döberl, 2007, but differs immediately in form of aedeagus, having specific apical protuberance, which resembles same of $H$. margitae Döberl, 2007, but much longer and with acute angles on sides.

ETIMOLOGY. I dedicate this species to my friend Manfred Döberl, eminent specialist in Alticinae, who also revised this large and difficult genus.

\section{Lanka nigricollis Medvedev sp.n. Figs 5, 11}

MATERIAL. Holotype: $\bigcirc^{7}$, Thailand, Mae Hong Son, env. Pai, 8-11.XI.2009, leg. N. Vikhrev (cLM).

DESCRIPTION. Red; prothorax, rather broad lateroapical margin of elytra (Fig. 5), hind femora except bases and hind tibiae black, two apical antennal segments infuscate.

Body elongate ovate. Head impunctate, deeply excavated near eyes, frontal tubercles absent, interantennal space narrow and carinate, clypeus triangular. Antennae reach middle of elytra. Proportions of segments are as 7-4-5-5-5-5-5-66-6-8, preapical segments not thickened, about 2.5 times as long as wide. Prothorax 1.6 times as wide as long, anterior angles thickened and oblique, angulate in anterior quarter, side margins behind angulation almost straight, surface shining and convex, slightly flattened near base, with fine and sparse but very distinct punctures. Scutellum triangular, small, shining. Elytra 1.25 times as long as wide, with distinct humeral tubercle, without basal convexity, surface shining, elytral rows thin and quite regular, interspaces flat and broad. Segment 1 of anterior tarsus strongly widened, triangular. Hind tibia thick, widened to apex, with short thick spur, hind tarsal segment 1 thin, about half of tibia length. Abdominal process of the first sternite with two sharp and parallel ridges, going to the middle of sternite. Aedeagus (Fig. 11) slightly widened to triangular apex, with deep preapical groove on underside. Length of body $2.2 \mathrm{~mm}$.
DIAGNOSIS. Near L. azumai Kimoto, 2000 from Thailand, differs with smaller size, black emargination of elytra and other colour of antennae. From L. brunnea Maulik, 1926 differs by the red head, bicolor elytra and quite other form of aedeagus.

ETIMOLOGY. The species named after the coloration of pronothum.

\section{Paraphthona opaca Medvedev sp.n.}

Fig. 12

MATERIAL. Holotype: $\sigma^{7}$, Thailand, Chonburi, Fomtien, 27.X.2009, leg. N. Vikhrev (cLM).

DESCRIPTION. Pale fulvous, labrum, scutellum, very narrow sutural stripe, sides of metasternum and apices of hind femora black, antennae piceous with 4 basal segments fulvous.

Body elongate. Clypeus short, with thin central ridge, interantennal space narrow and ridged, frons and vertex impunctate, frontal tubercles transverse, delimited behind with deep groove. Antennae reach middle of elytra, proportions of segments are as $10-5-8-8-8-8-8-8-8-8-11$, preapical segments about twice as long as wide. Prothorax 1.5 times as wide as long, broadest at base, moderately narrowed anteriorly, with side margins very feebly rounded, almost straight, surface feebly convex, dull, impunctate. Scutellum triangular with rounded apex. Elytra 1.3 times as long as wide, elongate ovate, broadest in middle, surface dull, impunctate, very finely and densely microsculptured, with basal convexity. Pygidium with rounded apex. Segment 1 of anterior tarsi strongly widened. Hind tibia almost as long as femur, straight, moderately widened to apex, spur very short. tarsal segment 1 about half of tibia length, flattened, about 3 times as long as wide at apex. Aedeagus thin and long, narrowed in middle area, with elongate triangular apex, side margins not angulate before apex (Fig. 12). Length $3.5 \mathrm{~mm}$.

DIAGNOSIS. This is the third species of the genus, all of them are from Thailand. They might be divided by the key.

ETIMOLOGY. The species named after the opaque elytrae.

1(2) Hind femora entirely black. Frontal tubercles strongly transverse. Elytra shining, impunctate. Aedeagus - Fig. 13. Length $3.7 \mathrm{~mm}$......... P. geiseri L. Medvedev, 2009 2(1) Hind femora fulvous with black apices. Elytra dull.

3(4) Frontal tubercles subquadrate. Elytra finely and densely punctate. Preapical antennal segments about 5 times as long as wide. Aedeagus - Fig. 14. Length $2.8 \mathrm{~mm}$. .... P. mostovskyi L. Medvedev, 2009

4(3) Frontal tubercles transverse. Elytra impunctate, with dense microsculpture. Preapical antennal segments about twice as long as wide. Aedeagus - Fig. 12. Length 3.5 mm.................................................. P. opaca $\mathbf{s p . ~ n . ~}$

ACKNOWLEDGEMENTS. I am grateful to Dr. M. Brancucci for the possibility to study materials under his care.

\section{References}

Jacoby M. 1889. List of the Phytophagous Coleoptera obtained by Signor L. Fea in Burma and Tenasserum with description of the new species // Ann. Mus. Civ. Stor. Natur. Genova. Vol.27. P.147-237.

Jacoby M. 1908. Fauna of the British India, including Ceylon and Burma. London: Francis \& Taylor. 534 pp.

Mohamedsaid M.S. 2004. Catalogue of the Malaysian Chrysomelidae. Sofia-Moscow: Pensoft. 239 pp. 